it is as much as can be assimilated as a first lesson in the great doctrine it discusses. It construes the atonement not in terms of abstract law, but rather as a necessity grounded in the needs of man and the nature of God and the moral kingdom.

E. Y. Mullins.

The Validity of the Religious Experience: A Preliminary Study in the Philosophy of Religion. By George A. Barrow, Ph.D., (Harv.). Boston, 1917, Sherman, French \& Co. $x i-\mid-247$ pp. $\$ 1.50$ net.

When in the first few lines of a book one twice finds phenomena used as a singular noun one is inclined to lay that book gently aside. In this case it would be a mistake. The author's style is not the most lucid and engaging at all times but it is usually fairly easy to follow, the proof-reader did better after he got started, the thought is profound and new and the course of the reasoning suggestive. One does not wonder that the seven lectures making up the volume were well received at Harvard.

The title describes the aim of the work-to show that religious experience is valid, objective, reliable and scientifically suited for use in theology and in the philosophy of religion. The lectures dealing with the Source of Religion, the Test of Religion, the Transcendence of the Human in the Superhuman in the religious relation, and Personality in the Object of Religion contain close reasoning and make a contribution to the argument for the validity of religion that is very gratifying.

\title{
II. MISSIONS.
}

W. O. Carver.

From Romance to Reality: The Merging of a Life in a World Movement: An Autobiography. By Henry Clay Mabie, D.D., LL.D., Author of "In Brightest Asia," etc., etc. Boston, MCMXVII. Printed for the Author (Roslindale, Mass.) 396 pp. $\$ 2.00$ net.

Dr. Mabie has been granted the persistence of his powers for an unusually long career of active service. For something like a decade his time has been largely at his own disposal while 
he filled a lectureship of a quite general character, whose times and terms were largely of his own choosing. He came into this period after a rich experience in pastoral service and then as missionary secretary. He had traveled widely not only in America but in Europe and Asia. Always a soul of broad sympathies and of profound religious experiences, he beeame a student of world movements and cosmic forces. More and more the Christ of God, achieving redemption through atonement, became the interpretative principle of all Dr. Mabie's thinking. In this last period of his ministry he has had occasion to go to all the European countries and to the chief centers of Asia, where his time and position gave him opportunities for study and personal association which he has utilized for defining his thoughts into something of a definite system.

Never lacking in idealism and wholesome ambition, Dr. Mabie has maintained a splendidly self-conscious personality which no deceptive humility holds back from frank expression where one may serve Christ in teaching men.

The outcome is an unusually elaborate autobiography in which the subject reveals himself and his interest in the "World Movement" of the Gospel Kingdom with a frank unreserve that is always interesting and suggestive.

The main title is intended to profess in the author, and to encourage in youth, the early cherishing of romantic ideals which through consecration can become realized in experience, not, to be sure, in the exact forms of youth's picturing but in the finer figuring of a divine planning. The secondary title suggests the highest end of a life, for nothing can be more worthful for a human life than to be merged in God's movement in world history.

An interest so broad, an experience so cosmopolitan, a personality so vital could not but bring together a record rich in narrative, description and philosophy. It is written in a way that makes most easy reading. Of course in so extensive a work one can find points for criticism and objection. There are omissions in mentioning persons not easy to understand. Claiming Dr. R. T. Bryan of China as a Northern Baptist is surprising! etc. Eucken was so gracious and congenial upon Dr. Mabie's 
visit that he was unable rightly to estimate Eucken's defects. The account of his retirement from the secretaryship of the Baptist Missionary Union, always, as the author says, a sort of mystery to some of his friends, is given with delicacy. But the criticisms of the Northern Convention, even so moderately expressed, are of doubtful propriety now that the Convention is definitely organized and its policies settled so far as the relation of the missionary societies goes. An index would be of decided advantage to the work. I suppose the book must be patronized by some wealthy friend or it could not be sold for two dollars. Any dealer can get it for you.

W. O. Carver.

Missionary Education in Home and School. By Ralph E. Diffendorfer. New York and Cincinnati, 1917. The Abingdon Press, 407 pp. $\$ 1.50$ net.

Mr. Diffendorfer has had fifteen years' experience in the field he here outlines and his competency is everywhere evident in the pages of this work. He practically identifies missions, social service, evangelism and personal religion. This identification, while in accordance with a true interpretation of the source of all religious life and service, does not contribute at all times to definiteness. It is easy to see that in the author's own thinking social service is really the primary interest, which is natural for one thinking and laboring in the sphere and atmosphere of his studies and work.

He brings to us, first of all, an outline of Principles in ten chapters. Then in seven further chapters he tells us how to apply and develop these principles in the various grades of education, from children to adults, following the system of grading in its chief divisions, now in use in Sunday Schools. Each chapter has a series of question topics "for further study and discussion" and "references" to literature for extension of one's investigations. It is all splendidly done, only the subject is properly "Practical Christianity in Religious Education" and not, as the title reads, "Missionary Edueation, ete." 